\title{
Ascogregarina (Apicomplexa: Lecudinidae): An overview of its distribution and pathogenicity on Aedes aegypti and Ae. albopictus development
}

\author{
Thiago Nunes Pereira ${ }^{1}$ \\ Josiane Somariva Prophiro ${ }^{2}$ \\ Guilherme Liberato da Silva ${ }^{1,3}$ \\ Joice Guilherme de Oliveira ${ }^{2}$ \\ Onilda Santos da Silva ${ }^{1 *}$ \\ ${ }^{1}$ Departamento de Microbiologia, Imunologia e Parasitologia, ICBS \\ Universidade Federal do Rio Grande do Sul \\ Rua Sarmento Leite, 500, CEP 90050-170, Porto Alegre - RS, Brasil \\ ${ }^{2}$ Departamento de Ciências da Saúde, Grupo de Pesquisa em Imunoparasitologia \\ Universidade do Sul de Santa Catarina \\ Avenida José Acácio Moreira 787, CEP 88704-900, Tubarão - SC, Brasil \\ ${ }^{3}$ Laboratório de Acarologia, Tecnovates, Universidade do Vale do Taquari \\ CEP 95914-014, Lajeado - RS, Brasil \\ * Autor para correspondência \\ onilda.silva@ufrgs.br
}

Submetido em 13/09/2017

Aceito para publicação em 01/08/2018

\section{Resumo}

Visão geral da distribuição de Ascogregarina (Apicomplexa: Lecudinidae) e seu papel no desenvolvimento biológico de Aedes aegypti e Ae. albopictus. As ascogregarinas são protozoários, pertencentes ao filo Apicomplexa, que parasitam várias espécies de invertebrados, incluindo algumas importantes espécies de mosquitos envolvidas na transmissão de arboviroses, como dengue, febre amarela, chikungunya e zika. As espécies gregarinas mais frequentemente reportadas em mosquitos são Ascogregarina culicis, A. taiwanensis e A. barreti, as quais possuem Aedes aegypti, Ae. albopictus e Ae. triseriatus como hospedeiros naturais, respectivamente. Estudos têm demonstrado que o parasitismo de algumas espécies de Ascogregarina pode influenciar negativamente o desenvolvimento biológico desses mosquitos e tal influência depende da sua distribuição ambiental. Assim, nesta revisão, foi verificada a distribuição de espécies de Ascogregarina em vários países, bem como sua influência no desenvolvimento de mosquitos e seu possível uso como controle destes insetos.

Palavras-chave: Arboviroses; Controle de mosquitos; Parasitismo

\section{Abstract}

Ascogregarina species are protozoa that belong to the phylum Apicomplexa and parasitize several species of invertebrates, including some important mosquito species involved in transmitting arboviruses, such as dengue, yellow fever, chikungunya and Zika virus. The most frequent gregarine species reported for mosquitoes are 
Ascogregarina culicis, A. taiwanensis and A. barreti, which have Aedes aegypti, Ae. albopictus and Ae. triseriatus as natural hosts, respectively. Studies have shown that parasitism by some Ascogregarina species can negatively influence the biological development of mosquitoes and that this influence depends on their environmental distribution. In this review, we revise the distribution of Ascogregarina species in several countries and discuss how these parasites influence the development of mosquitoes and could possibly be used as a mosquito control.

Key words: Mosquito control; Parasitism; Vector-borne diseases

\section{Introduction}

Some mosquito species, such as Aedes aegypti Linnaeus and Ae. albopictus Skuse, are globally important vectors of diseases and are responsible for transmitting arboviruses, such as dengue, yellow fever, chikungunya (GUBLER, 2011; STAPLES; FISCHER, 2014), Mayaro virus (VIEIRA et al., 2015), and Zika virus (CHOUIN-CARNEIRO et al., 2016). Dengue is considered one of the most important arboviruses due to high morbidity and mortality, and because of large epidemics in several regions around the world, especially in tropical and subtropical countries (GUZMAN; HARRIS, 2015). The chikungunya virus has also caused serious epidemics in various parts of the world and, in most cases, its symptoms are very similar to dengue. However, sometimes the infection causes strong inflammation in the joints that leads to severe pain in the patient due to persistent arthralgia (MONTERO, 2015; WEAVER; FORRESTER, 2015). Arthralgia can also be the most severe and prominent manifestation of a Mayaro virus infection, which is found in South America (VIEIRA et al., 2015).

More recently, another neglected arthropod virus, called the Zika virus, emerged in Brazil in 2015. Since then, this disease has spread rapidly within the Americas, giving rise to several cases of congenital malformations and neurological syndromes (HEUKELBACH et al., 2016).

Both Ae. aegypti and Ae. albopictus are distributed worldwide, from tropical to temperate climates, and occupy all of Brazil (KRAEMER et al., 2015) where millions of dengue, chikungunya and Zika outbreaks have been reported annually, mainly in the Northeast Region of the country. Another important species responsible for transmitting arboviruses is Ae. triseriatus Say. This is an invasive mosquito species that is prevalent in the United States, where it is responsible for transmitting the La Crosse virus (JONES et al., 1999; BORUCKI et al., 2001; WESTBY et al., 2015). However, this species has been recently reported in Mexico (SÁNCHEZ-TRINIDAD et al., 2014). A study conducted by Trout Fryxell et al. (2015) demonstrated the natural infection of Ae. triseriatus by the La Crosse virus based on larvae collected in a cemetery that were screened for LACv using RT-PCR.

The ability of Ae. triseriatus to utilize artificial container habitats for larvae development, like Ae. aegypti and Ae. albopictus, suggests that this species could easily become established in Latin America.

Controlling the vectors is the main method used to avoid arboviruses, which can be done by naturally managing artificial breeding places of mosquito larvae. A second method is to apply biological and chemical products when using integrated management in environmental programs (SALOKHE et al., 2012; SILVA et al., 2013; ARAÚJO et al., 2015; CAIXETA et al., 2016). Among these applications, chemical control may promote the selection of resistant populations (PROPHIRO et al., 2011; BELLINATO et al., 2016; SMITH et al., 2016) and cause other problems, such as adverse effects on non-target organisms, high cost and environmental damage, since most applied insecticides are not biodegradable (BLAIR et al., 2000). Environmentally friendly alternatives have been explored to help reduce the selection pressure for insecticide resistance. Biocontrol strategies include natural organisms that exploit mosquito behaviour to increase mosquito mortality and releasing mosquitoes that are either sterile or unable to transmit disease (BENELLI et al., 2016). This control method is advantageous because it employs organisms that have target specificity, does not cause environmental pollution 
and has a lower risk of selecting resistant populations (GARCIA et al., 2016). Some examples of biocontrol strategies are growth regulators that act through chitin synthesis inhibitors, and behaviour modifiers that can be generated by viruses, bacteria, fungi, and protozoa (LELES et al., 2012; LU et al., 2012; OTTA et al., 2012; SILVA et al., 2013). As demonstrated, Ae. aegypti and Ae. albopictus are potential vectors of a number of arboviruses. Each of these mosquito species can naturally harbour a specific gregarine parasite that allows the host mosquito to carry out life functions while remaining relatively unaffected by its presence (MORALES et al., 2005). Among these protozoa, some species of Ascogregarina are highly prevalent in natural populations of some mosquito species (BLACKMORE et al., 1995). The most studied species are A. taiwanensis, A. culicis and A. barreti, which parasitize Ae. Albopictus, Ae. aegypti and Ae. triseriatus, respectively.

\section{Gregarines}

The phylum Apicomplexa, which includes Ascogregarina spp., is represented by obligate protozoan parasites. Their invasive form is characterized by the presence of a single apical complex responsible for penetration and cell invasion (MORRISON, 2009), usually in the intestine, coelom and reproductive tissues of invertebrates (LEANDER, 2008). The genera
Ascogregarina (syn. Monocystis von Stein, Lankesteria Mingazzini and Ascocystis Grasse) and Psychodiella (Eugregarinorida: Aseptatorina) have recently been included in the new family Ascogregarinidae. Previously, species that parasitize mosquitoes and sandflies belonged to a single genus: Ascogregarina (DESPORTES, 2013). However, recently, they were placed in two genera: (1) Ascogregarina, represented by species that parasitize mosquitoes, flies and fleas; and (2) Psychodiella, represented by species that parasitize sandflies (LANTOVA; VOLF, 2014). The classification using trophozoites is based on parasite habitats, host diversity and morphological characteristics (VIVIER; DESPORTES, 1990).

It is estimated that there are many unknown species that parasitize different invertebrate hosts (CLOPTON, 2000; HAUSMANN et al., 2003; DESPORTES, 2013). Host species of terrestrial gregarines have mostly been reported to be insects, including aquatic insects, coleopterans and dipterans (VOTÝPKA et al., 2009). Until now, few species of Ascogregarina that parasitize mosquitoes have been described (BEIER; CRAIG, 1985; CHEN, 1999; LANTOVA; VOLF, 2014). The most well-known species are $A$. culicis, $A$. taiwanensis and A. barretti (Table 1). These species are morphologically similar, except for the size and shape of their oocysts and gamonts (ROYCHOUDHURY; KOBAYASHI, 2006).

TABLE 1: Reports about worldwide distribution of Ascogregarina species in wild populations of mosquitoes.

\begin{tabular}{|l|c|c|c|c|l|}
\hline $\begin{array}{c}\text { Ascogregarina } \\
\text { species }\end{array}$ & Host species & $\begin{array}{c}\text { Oocyst } \\
\text { length }\end{array}$ & $\begin{array}{c}\text { Trophozoite } \\
\text { length }\end{array}$ & Country & \multicolumn{1}{|c|}{ Reference } \\
\hline & & $5-10 \mu \mathrm{m}$ & $*$ & Taiwan & Lien and Levine (1980) \\
\hline & & $*$ & $*$ & USA & Reinert (2000) \\
\hline & & $*$ & $*$ & USA & Blackmore et al. (1995) \\
\hline & & $8.3-9.9 \mu \mathrm{m}$ & $*$ & USA & Garcia et al. (1994) \\
\hline & & $* .72 \mu \mathrm{m}$ & $*$ & Taiwan & Chen et al. (1997) \\
\hline & & $*$ & $*$ & USA & Comiskey (1999) \\
\hline & & $9.9 \mu \mathrm{m}$ & $*$ & USA & Reyes-Villanueva et al. (2003) \\
\hline & & $*$ & $80 \mu \mathrm{m}$ & Bapan & Roychoudhury et al. (2007a) \\
\hline & & $*$ & $50-621 \mu \mathrm{m}$ & Brazil & Passos and Tadei (2008) \\
\hline & & $*$ & $*$ & Mexico & Reyes-Villanueva et al. (2013) \\
\hline & Ae. aegypti (Linnaeus) & $*$ & $*$ & USA & Garcia et al. (1994) \\
\hline & & $*$ & $*$ & Brazil & Prophiro et al. (2017) \\
\hline
\end{tabular}




\begin{tabular}{|c|c|c|c|c|c|}
\hline A. culicis & & $6 \mu \mathrm{m}$ & $*$ & India & Ross (1898) \\
\hline & & $*$ & $*$ & USA & Hayes and Haverfield (1971) \\
\hline & & $*$ & & India & Beier et al. (1995) \\
\hline & & $*$ & $*$ & Brazil & Marchoux et al. (1903) \\
\hline & & $10-12 \mu \mathrm{m}$ & $*$ & $*$ & Vavra (1969) \\
\hline & & $11 \mu \mathrm{m}$ & $*$ & $*$ & Lien and Levine (1980) \\
\hline & Ae. aegypti (Linnaeus) & * & $*$ & USA & Blackmore et al. (1995) \\
\hline & & $*$ & $*$ & India & Beier et al. (1995) \\
\hline & & $9.5-12.2 \mu \mathrm{m}$ & $*$ & Argentina & Dellape et al. (2005) \\
\hline & & $*$ & $*$ & USA & Reyes-Villanueva et al. (2003) \\
\hline & & $\begin{array}{c}10.6-11.4 \\
\mu \mathrm{m}\end{array}$ & $*$ & Argentina & Vezzani and Wisnivesky (2006) \\
\hline & & $*$ & 76.9-116.5 $\mu \mathrm{m}$ & Argentina & Albicócco and Vezzani (2009) \\
\hline & & * & $60 \mu \mathrm{m}$ & Brazil & Passos and Tadei (2008) \\
\hline & & $8.8 \mu \mathrm{m}$ & $*$ & Not cited & Roychoudhury et al. (2007a) \\
\hline & Ae. geniculatus (Olivier) & $12 \mu \mathrm{m}$ & $*$ & England & Ganapati and Tate (1949) \\
\hline & & $11 \mu \mathrm{m}$ & $150-310 \mu \mathrm{m}$ & USA & Vavra (1969) \\
\hline \multirow[t]{5}{*}{ A. barrenti } & Ae. triseriatus (Say) & $*$ & $*$ & USA & Beier and Harris (1983) \\
\hline & & $*$ & $*$ & USA & Porter and Defoliar (1985) \\
\hline & & $*$ & $*$ & USA & Blackmore et al. (1995) \\
\hline & & * & $*$ & USA & Comiskey et al. (1999) \\
\hline & & $*$ & $*$ & USA & Van Rhein et al. (2000) \\
\hline \multirow[t]{2}{*}{ A. tripteroidesi } & $\begin{array}{l}\text { Tripteroides dofleini } \\
\text { (Guenther) }\end{array}$ & $*$ & $*$ & Sri Lanka & Guenther (1914) \\
\hline & & $*$ & $*$ & India & Bhatia (1938) \\
\hline A. clarki & Ae. sierrensis (Ludlow) & $10-12 \mu \mathrm{m}$ & $129.1 \mu \mathrm{m}$ & USA & Sanders and Poinar (1973) \\
\hline A. lanyuensis & Ae. alcasidi (Huang) & $9 \mu \mathrm{m}$ & $190 \mu \mathrm{m}$ & Taiwan & Lien and Levine (1980) \\
\hline \multirow[t]{2}{*}{ A. armigerei } & $\begin{array}{c}\text { Armigeres subalbatus } \\
\text { (Coquillett) }\end{array}$ & $14.5 \mu \mathrm{m}$ & $*$ & Taiwan & Lien and Levine (1980) \\
\hline & & $13.2 \mu \mathrm{m}$ & $*$ & $*$ & Roychoudhury et al. (2007a) \\
\hline \multirow[t]{2}{*}{ A. geniculati } & Ae. geniculatus (Olivier) & $9-11 \mu \mathrm{m}$ & $*$ & Czech Republic & Kramar (1952) \\
\hline & & $13.5 \mu \mathrm{m}$ & $*$ & Italy & Munstermann and Levine (1983) \\
\hline A. polynesiensis & Ae. polynesiensis (Marks) & $9.32 \mu \mathrm{m}$ & $35-65 \mu \mathrm{m}$ & $\begin{array}{c}\text { Independent } \\
\text { State of Samoa } \\
\end{array}$ & Pillai et al. (1976) \\
\hline A. japonicus & $\begin{array}{l}\text { Ochlerotatus japonicus } \\
\text { (Theobald) }\end{array}$ & $*$ & $*$ & Japan & Roychoudhury et al. (2007b) \\
\hline
\end{tabular}

* Not mentioned 


\section{The life cycle of Ascogregarina spp.}

The life cycle of Ascogregarina spp. is based on A. taiwanensis and A. culicis, since they are the most studied species that parasitize mosquito vectors. The life cycle of gregarines is similar between these two species and begins with the ingestion of mature oocysts by an invertebrate host (CHEN, 1999; TSENG, 2007).

In this work, the description is based on the relationship between A. taiwanensis and Ae. albopictus (Figure 1). The asexual cycle begins when oocysts that contain sporozoites are ingested by mosquito larvae. After a few minutes, sporozoites are released and undergo an intracellular phase in the epithelial cells of the foregut (ROYCHOUDHURY; KOBAYASHI, 2006). In different hosts, they can also invade other organs, such as the coelom and reproductive tissues (BEIER; CRAIG, 1985; LEANDER, 2008). After a short intracellular phase, sporozoites leave the epithelial cells to form extracellular trophozoites that fix themselves to the epithelium by their epimerites (CHEN et al., 1997). These trophozoites are found mostly in a posterior portion of the midgut, where vacuolar $\mathrm{H}+\mathrm{ATPase}$ (V-ATPase) is actively expressed (HUANG et al., 2006). The trophozoites of $A$. taiwanensis in the midgut of mosquito larvae normally mature alongside host development (CHEN; YANG, 1996). Based on molecular markers, Chen (1999) observed that only $50 \%$ (or less) of A. taiwanensis trophozoites successfully migrate. An ultra-structural study made by Chen et al. (2013) showed that trophozoites that failed to migrate were retained in the midgut of mosquito pupae. The rest generally die by necrosis or apoptosis (KANDUC et al., 2002). Chen et al. (2013) also observed degradation of chromosomal DNA and detection of caspase-like activity. DNA fragmentation also appeared in extracted

FIGURE 1: The asexual (A) and sexual (B) reproduction life cycle of Ascogregarina taiwanensis parasitizing Aedes albopictus; 1: trophozoite stage; 2-5: gamete fusion, gametocyte and oocyst formation; 6: release of oocysts; 7: oocysts; 8: sporozoites. Modified from Vivier and Desportes (1990).

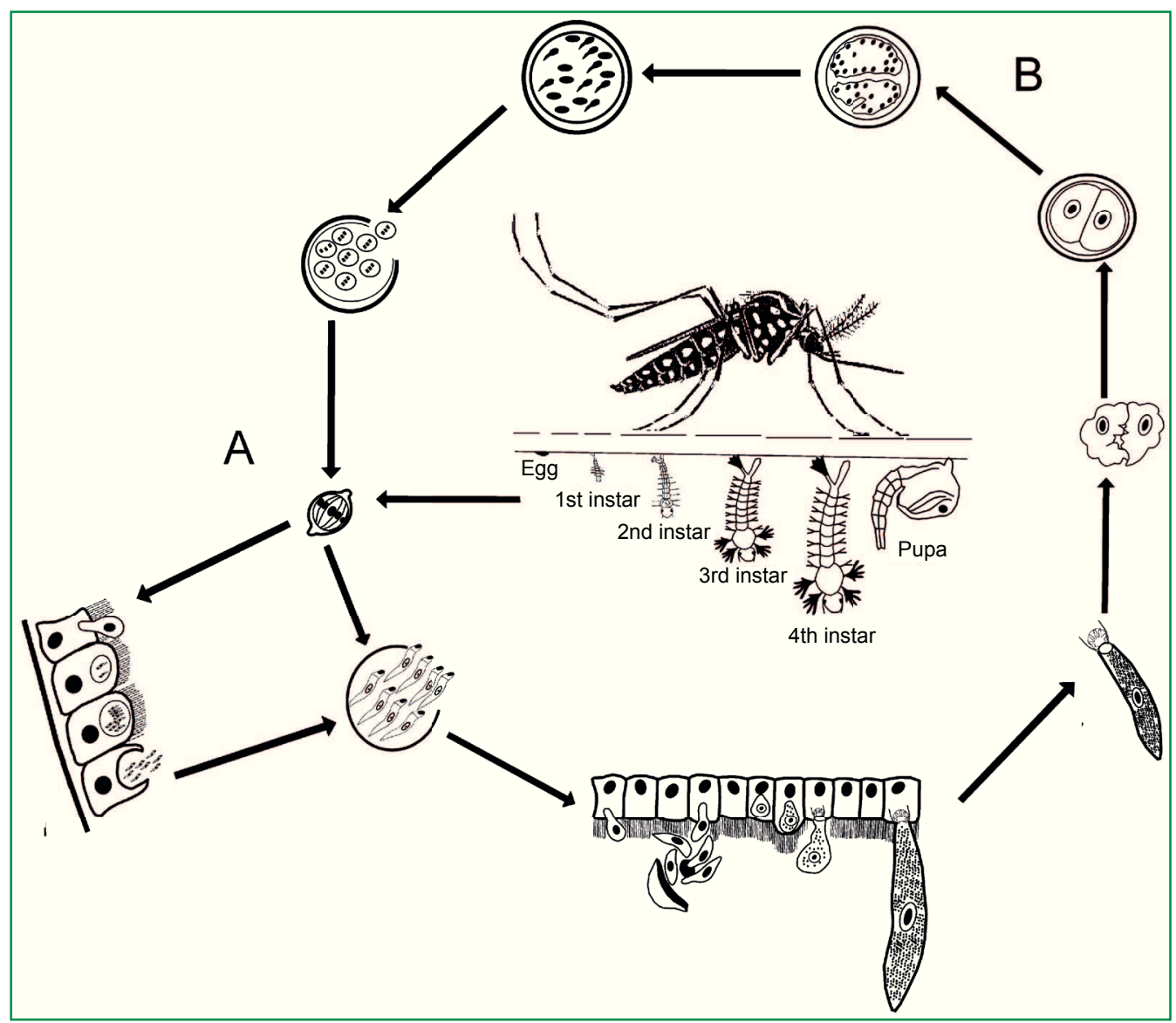


genomic material, implying that apoptosis occurred in most, if not all trophozoites that did not successfully migrate.

When mature trophozoites develop into gamonts in the midgut lumen of larvae, as well as in the pupal stage, they migrate to Malpighian tubules due to their gliding motility, where their sexual cycle (gametogony) and posterior fusion of gamonts occurs (WETZEL et al., 2003). Migration of Ascogregarina spp. from the midgut to Malpighian tubules is unidirectional and generally occurs between the trophozoites that were released in the midgut of early pupae, usually five hours after pupation (CHEN; FAN-CHIANG, 2001). The size of mature gamonts is extremely variable and dependent on the host and its geographic distribution (GARCIA et al., 1994). Sexual reproduction results in the formation of gametocysts, wherein true gametes are formed by nuclear division and cytokinesis. Fertilization occurs by the fusion of two gametes in the gametocyst, resulting in oocyst production with eight sporozoites (CHEN et al., 1997).

The possible routes for dissemination of the parasite occur when pupae or emerged adult mosquitoes infected with oocysts die at the site of reproduction, or when oocysts are released when adults emerge. The transmission can also occur at the time of oviposition, when infected females release oocysts together with their eggs (BEIER; CRAIG, 1985; LEANDER, 2008).

In most Ascogregarina species, oocysts can persist 4-6 months (on average) without water (ROYCHOUDHURY; KOBAYASHI, 2006). Chen and Yang (1996) showed that under laboratory conditions the optimum temperature for $A$. taiwanensis development is $24^{\circ} \mathrm{C}$. They observed that a temperature as high as $29^{\circ} \mathrm{C}$ shortened the development period of this parasite, and most oocysts failed to mature. In addition, gametocysts did not form if the mosquito remained in the larval stage at $14^{\circ} \mathrm{C}$, indicating that the development of the parasite may also be influenced by host hormone levels.

\section{Identification of Ascogregarina spp.}

In terms of Ascogregarina parasites of mosquitoes, Comiskey et al. (1999) stated that A. barretti, A. culicis, and $A$. taiwanensis could sometimes occur in the same breeding places. Although $A$. barretti trophozoites can be visually distinguished from the other two parasite species in mosquito midgut infections, it is difficult to distinguish between A. taiwanensis and A. culicis because they have a similar size and morphology (Lien and Levine 1980). Thus, an accurate identification is necessary, mainly because these parasites can sometimes parasitize both Ae. aegypti and Ae. albopictus.

Beier and Harris (1983) evaluated the cross infection of $A$. barretti and $A$. geniculate in Ae. triseriatus under laboratory conditions. To distinguish these gregarine species, the authors subjected them to isoenzyme electrophoresis. The isocitrate dehydrogenase bands of each were clearly distinguishable on the same electrophoretic track. This technique appears to be a reliable method for resolving taxonomic complications of gregarines in mosquitoes.

Since oocysts are the only free-living stage of Ascogregarina parasites, and it is not easy to identify a difference in size among species, it is quite difficult to identify the parasites based solely on microscopic observations of oocysts. Therefore, studies to identify these parasites using subunit ribosomal DNA (SSU rDNA) have proved to be highly informative for phylogenetic studies and species identification (ROYCHOUDHURY et al., 2007a).

Reyes-Villanueva et al. (2001) described morphological characteristics to determine Ascogregarina spp. using gamonts of $A$. taiwanensis. They have a yellow granular cytoplasm, visible using phase-contrast microscopy, while those of $A$. culicis have a crystalline cytoplasm. However, according to Morales et al. (2005), morphological differentiation of gamonts involves dissection, which requires considerable technical skill and careful timing to reliably view extracellular gamonts. On the other hand, this may not always be reliable when dealing with mosquito larvae collected in the field, which can consume oocysts of both gregarine species at different times during larval development, resulting in trophozoites and gamonts of varying ages in an individual larva. Blackmore et al. (1995) already described such difficulties in identifying $A$. taiwanensis and $A$. culicis parasitizing Ae. aegypti and Ae. albopictus 
competing in the same breeding places. Based on these reports, Morales et al. (2005) developed specific primers for identifying Ascoregarina species using PCR. This technique was very useful for confirming that $A e$. aegypti and Ae. albopictus, collected in southern Brazil, harboured A. taiwanensis (PROPHIRO et al., 2017).

\section{Pathogenicity of Ascogregarina spp. during mosquito development}

Among the reported species, A. taiwanensis, $A$. culicis and $A$. barretti are the most frequent parasites of mosquitoes in several countries (REEVES, 2004). Various authors have reported that these parasites have low or no pathogenicity on their natural hosts (WALSH; OLSON, 1976; BEIER; CRAIG, 1985; COPELAND, CRAIG; 1992; YEH et al., 1994). Furthermore, some authors suggest that their pathogenicity may vary according to the geographical distribution of vectors.

Barrett (1968) was the first author to report that A. culicis is highly pathogenic to Ae. aegypti. After this report, several surveys and tests were conducted in the United States in order to verify the potential role of $A$. culicis for the biocontrol of Ae. aegypti, since a strain of $A$. culicis originating from the United States is considered non-pathogenic (BARRETT, 1968). In observations made by McCray et al. (1970) in Georgia, USA, A. culicis did not affect larval development, size, mortality, pupal weight and adult emergence of Ae. aegypti. However, Barrett et al. (1971) observed that $A$. culicis had an adverse effect on Ae. aegypti by reducing host fecundity. Gentile et al. (1971) studied the distribution of $A$. culicis parasitizing Ae. aegypti by the distribution of oocysts in the USA. They observed that the parasites apparently had few deleterious effects on the host populations. Hayes and Haverfield (1971) conducted a survey in Florida, USA, and suggested that $A$. culicis did not exert a serious limiting effect on Ae. aegypti populations. Stapp and Gasten (1971) also inspected $A e$. aegypti larvae for infection with $A$. culicis throughout cities in Florida. Generally, larvae infection was not high. The authors suggested that the levels of A. culicis infection in Ae. aegypti larvae could be increased by introducing parasite sporocysts into potential breeding containers.
On the other hand, four strains of $A$. culicis from Thailand were pathogenic to Ae. aegypti, causing atrophy and increased mortality of larvae and pupae (SULAIMAN, 1992). In Malaysia, this author evaluated the susceptibility of three strains of Ae. aegypti to four strains of $A$. culicis under laboratory conditions. The parasite was found to be pathogenic to the mosquito, the level of pathogenicity varied among geographical strains of $A$. culicis, and susceptibility varied among geographical strains of Ae. aegypti. In addition, infection with the parasite was found to shorten the mosquito larval development time.

In relation to Ae. albopictus, Comiskey et al. (1999) observed that A. taiwanensis collected in New Orleans, USA, negatively influenced the performance of this mosquito species only when larvae were poorly fed. According to Munstermann and Wesson (1990), Ae albopictus is often heavily parasitized by A. taiwanensis. These protozoan parasites have been frequently described as having different levels of pathogenicity on their natural hosts (WALSH; OLSON, 1976; BEIER; CRAIG, 1985; COPELAND; CRAIG, 1992). Garcia et al. (1994) studied the prevalence of A. taiwanensis in larvae of Ae. albopictus and found minimum values (68\%) in April, which increased to a maximum (100\%) in August and then decreased in the winter.

Pathogenic effects on hosts are probably related to the negative impact on tissues where parasites develop. When mosquito larvae are infected, the epithelial cells of the intestine extend their nucleus and can be destroyed by the parasites (KRAMAR, 1952; SANDERS; POINAR, 1973). Moreover, Malpighian tubules in adults become swollen (WENYON, 1911) and their cells become distorted and damaged (BARRETT, 1968; MCCRAY et al., 1970; SANDERS; POINAR, 1973). Furthermore, Barrett (1968) showed that the extent of this damage is proportional to the infection rate of parasites.

Under stressful conditions, A. taiwanensis increases larval mortality of Ae. albopictus, decreases female fecundity, prolongs male and female development (COMISKEY et al., 1999), and reduces A. albopictus oviposition and hatch rate (YEH et al., 1994). 
Prophiro (2013) analysed the influence of parasitism of A. taiwanensis on the biological development of the natural host Ae. albopictus under laboratory conditions. This author showed that the infected population had a lower survival rate, viability/hatching and number of eggs compared to the uninfected population.

Aedes triseriatus is a vector of the La Crosse encephalitis virus in North America (WESTBY et al., 2015). This species is commonly infected by $A$. barretti (WALKER et al., 1987). According to Craig (1993), their larvae can be found in tree holes, discarded tires, and other containers. Beier and Harris (1983) reported that $62 \%$ of the larvae and $35 \%$ of the adults collected from tree holes and discarded tire habitats in northern Indiana were infected by $A$. barretti. They also observed that parasitism of Ae. triseriatus by $A$. barretti extends the time of pupae development in males and diminishes pupae size of females, but induces no effect on larval survival, emergence or survival of adults. Similarly, Van Rhein et al. (2000) described that when A. barretti parasitizes Ae. triseriatus, female fecundity and size is reduced. Moreover, Porter and DeFoliart (1985) collected $A$. triseriatus in southern Wisconsin and found that $39 \%$ of adult females were infected by $A$. barretti. Also, Beier and Harris (1983) suggested that $A$. barretti is a relatively benign parasite of Ae. triseriatus. This author observed that infection did not affect larval mortality, adult emergence, or adult survival of $\mathrm{Ae}$. triseriatus. However, it produced some slight effects on female pupal weight and male development time under laboratory conditions. Porter and DeFoliart (1985) found more frequent infections in nulliparous than parous $A e$. triseriatus, but this difference cannot be definitively attributed to parasitism because mosquitoes may shed spores during oviposition.

Spencer and Olson (1982) observed low rates of egg hatching, larval survival and reduction in parasitized female weight in Ae. hendersoni, which is a non-natural host of $A$. barretti.

Garcia et al. (1994) observed that the level of pathogenicity in mosquitoes by a gregarine is not only influenced by sex and nutrients, but also because the parasite may be significantly more pathogenic when it is introduced in a non-natural host (e.g., when
A. taiwanensis infects Ae. taeniorhynchus). Other laboratory studies have shown that non-natural hosts of $A$. taiwanensis, for example, Ochlerotarus epactius (KnabDyar) (syn. Ae. epactius; see Reinert (2000), Ochlerotatus atropalpus (Coquillett) Munstermann and Wesson (1990) and Ochlerotatus taeniorhynchus (Wiedemann) (Garcia et al., 1994), are able to host this protozoon and provide it the necessary conditions to complete its life cycle. However, changes in fitness can occur, such as a decrease in wing size, life history and shortening of the pupal, among others (GARCIA et al., 1994). Comiskey et al. (1999) stated that when these protozoa infect Ae. aegypti they are usually unable to fully develop and can cause morbidity or kill the host. According to Reeves (2004), if mosquitoes suffer significant mortality due to gut symbionts in nature, then females might avoid water contaminated with these organisms. However, the rearing water from larvae infected with $A$. taiwanensis was more acceptable to ovipositing females than distilled water or rearing water from uninfected larvae. Earlier, Reeves and McCullough (2002) infected the Sabethine mosquito Wyeomyia smithii with $A$. taiwanensis and the parasite developed and invaded the Malpighian tubules in up to $70 \%$ of mosquitoes without causing any mortality. According to Comiskey et al. (1999), the negative effects of gregarines on host fitness can be exaggerated when hosts are crowded, underfed, or in competition. This may result from consumption of available resources by the parasite, or diversion of those resources for use by the host to repair damaged tissue and to elicit immune responses against the parasite.

\section{Conclusion and Perspectives}

Although most gregarines are often considered non-pathogenic to their natural hosts (HENRY, 1981), their impact on infected insects is not always clear because of a lack of knowledge about their biology and possible effects on their hosts. Laboratory studies have shown that non-natural hosts of Ascogregarina spp. can host these parasites, providing them with the means to complete their biological cycle. However, these parasites can negatively influence the development of the host. 
It is important to remember that Ae. albopictus and Ae. aegypti can coexist in the same breeding places (FANTINATTI et al., 2007; PROPHIRO et al., 2011; LOUNIBOS et al., 2016). This behaviour could be beneficial for Ae. albopictus in terms of competition, if the pathogenicity of Ascogregarina spp. becomes more significant to the non-natural host (Ae. Aegypti). When the level of parasitism within a population is high, negative effects have been reported, as previously cited by the above authors. Also, when parasitism begins in the host midgut, there is possible competition for nutrition resources (CHEN, 1999; ANDREADIS, 2007). In addition, extreme variations of physiological conditions associated with parasitic infection, toxins, or trauma can cause necrosis in cells, resulting in direct damage to the plasma membrane, which kills the host (GOLSTEIN; KROEMER, 2007). Moreover, mosquito populations parasitized by Ascogregarina spp. demonstrated that these protozoa influence competitive interactions between species of mosquitoes. For instance, this parasite may contribute to the competitive advantage of Ae. albopictus compared to Ae. triseriatus (ALIABADI; JULIANO, 2002). Therefore, the physiological impact caused by Ascogregarina parasites in mosquitoes requires further research.

According to Lima-Camara (2016), over the last 10 years we have seen the emergence of several diseases transmitted by mosquitoes, especially arboviruses (e.g., dengue, chikungunya, West Nile, Mayaro and Zika viruses) in different countries of the Americas. Compared to the United States (Table 1), in South America the distribution of Ascogregarina species and the pathogenic potential of these species to mosquito vectors are poorly known. There are only three publications describing the occurrence of $A$. taiwanensis and A. culicis in natural populations of Ae. aegypti and Ae. albopictus in Argentina (VEZZANI; WISNIVESKY, 2006) and Brazil (PASSOS; TADEI, 2008; ALBICÓCCO; VEZZANI, 2009; PROPHIRO et al., 2017). Therefore, it is very important to better understand the conditions that modify prevalence and infection intensity of Ascogregarina spp. in mosquitoes, in order to evaluate whether these parasites can really impact the host population.
As observed, various species of Ascogregarina are involved in the negative effects of mosquito fitness, which can be exploited as a new biocontrol tool. However, it is important to dedicate more studies to understanding the biology of mosquitoes parasitized with these protozoa. Such studies might clarify whether some effects are related to underfed larvae, or feeding competition with sibling species (e.g., Ae. aegypti and Ae. Albopictus) in the same breeding places, and other biological aspects that could be used as possible biocontrol strategies. In addition, a protocol for the mass reproduction of Ascogregarina is unknown. It is necessary to know if these protozoa can be mass reproduced, and how they could be released into the environment, under what conditions and at what costs.

Even when some Ascogregarina species do not play an important role in the biocontrol of some mosquito populations, they have been becoming increasingly important, since they could be involved in the maintenance of arboviruses in the breeding places of mosquitoes. Moury et al. (2003) obtained vertical transmission of the chikungunya virus through the oocyst of A. culicis in Ae. aegypti mosquitoes under laboratory conditions. They suggested that these protozoa may play an important role in the maintenance of the chikungunya virus during the inter-epidemic period. Thus, it is of great importance to determine whether $A$. taiwanensis and $A$. culicis could influence the replication and maintenance of arboviruses, such as dengue and Zika viruses, and consequently influence human infection.

\section{References}

ALBICÓCCO, A. P.; VEZZANI, D. Further study on Ascogregarina culicis in temperate Argentina: prevalence and intensity in Aedes aegypti larvae and pupae. Journal of Invertebrate Pathology, Riverside, v. 101, p. 210-214, 2009.

ALIABADI, B. W.; JULIANO, S. A. Escape from gregarine parasites affects the competitive interactions of an invasive mosquito. Biological Invasions, Dordrecht, v. 4, p. 283-297, 2002.

ANDREADIS, T. G. Microsporidian parasites of mosquitoes. Journal of the American Mosquito Control Association, Washington, v. 23, p. 3-29, 2007.

ARAÚJO, H. R.; CARVALHO, D. O.; IOSHINO, R. S.; COSTADA-SILVA, A. L.; CAPURRO, M. L. Aedes aegypti control strategies in Brazil: Incorporation of new technologies to overcome the persistence of dengue epidemics. Insects, Basel, v. 11, p. 576$594,2015$. 
BARRETT, W. L. Damage caused by Lankesteria culicis (Ross) to Aedes aegypti (L). Mosquito News, Albany, v. 28, p. 441, 1968.

BARRETT, W. L.; MILLER, F. M., KLIEWER; J. W. Distribution in Texas of Lankesteria culicis (Ross), a parasite of Aedes aegypti (L.). Mosquito News, Albany, v. 31, p. 23-27, 1971.

BEIER, J. C.; CHADEE, D. D.; CHARRAN, A.; COMISKEY, N. M.; WESSON, D. M. Country-wide prevalence of Ascogregarina culicis (Apicomplexa: Lecudinidae), a protozoan parasite of Aedes aegypti in Trinidad, West Indies. Journal of the American Mosquito Control Association, Washington, v. 11, p. 419-423, 1995.

BEIER, J. C.; CRAIG, G. B. Gregarine parasites of mosquitoes. In: LAIRD, M. (Ed.). Integrated mosquito control methodologies. Vol 2. London: Academic Press, 1985. p. 167-184.

BEIER, J. C.; HARRIS, C. Ascogregarina barretti (Sporozoa: diplocystidae) infections in natural populations of Aedes triseriatus (Diptera: Culicidae). Journal of Parasitology, Lawrence, v. 69, p. 430-431, 1983.

BENELLI, G.; JEFFRIES, C. L.; WALKER, T. Biological control of mosquito vectors: past, present, and future. Insects, Basel, v. 7, n. 4, 2016.

Biological Control of Mosquito Vectors: Past, Present, and Future. Insects 2016, 7, 52.

BELLINATO, D. F.; VIANA-MEDEIROS, P. F.; ARAÚJO, S. C.; MARTINS, A. J.; LIMA, J. B.; VALLE, D. Resistance status to the insecticides Temephos, Deltamethrin, and Diflubenzuron in Brazilian Aedes aegypti populations. BioMed Research International, Cairo, v. 2016, p. 8603263, 2016.

BHATIA, B. L. Protozoa: sporozoa. In: SEWELI, R. B. S. (Ed.). The fauna of British India. London: Taylor and Francis, 1938. p. 41-42.

BLACKMORE, M. S.; SCOLES, G. A.; CRAIG, G. B. Parasitism of Aedes aegypti and Ae. albopictus (Diptera: Culicidae) by Ascogregarina spp. (Apicomplexa: Lecudinidae) in Florida. Journal of Medical Entomology, Lanham, v. 32, p. 847-852, 1995.

BLAIR, C. D.; ADELMAN, Z. N.; OLSON, K. E. Molecular strategies for interrupting arthropod-borne virus transmission by mosquitoes. Clinical Microbiology Reviews, Washington, v. 13, p. 651-661, 2000.

BORUCKI, M. K.; KEMPF, B. J.; BLAIR, C. D.; BEATY, B. J. The effect of mosquito passage on the La Crosse virus genotype. Journal of General Virology, London, v 82, p. 2919-2926, 2001.

CAIXETA, E. S.; SILVA, C. F.; SANTOS, V. S.; OLEGÁRIO DE CAMPOS JÚNIOR, E.; PEREIRA, B. B. Ecotoxicological assessment of pyriproxyfen under environmentally realistic exposure conditions of integrated vector management for Aedes aegypti control in Brazil. Journal of Toxicology and Environmental Health, Ottawa, v. 79, p.799-803, 2016.

CHEN, W. J. The life cycle of Ascogregarina taiwanensis (Apicomplexa: Lecudinidae). Parasitology Today, Cambridge, v. 15, p. 153-156, 1999.

CHEN, W. J.; FAN-CHIANG, M. H. Directed migration of Ascogregarina taiwanensis (Apicomplexa: Lecudinidae) in its natural host Aedes albopictus (Diptera: Culicidae). Journal of Eukaryotic Microbiology, Cincinnati, v. 48, p. 537-541, 2001.

CHEN, W. J.; HUANG, C. G.; FAN-CHIANG, M. H.; LIU, Y. H.;
LEE, Y. F. Apoptosis of Ascogregarina taiwanensis (Apicomplexa: Lecudinidae), which failed to migrate within its natural host. Journal of Experimental Biology, Cambridge, v. 216, p. 230-235, 2013.

CHEN, W. J.; WU, S. T.; CHOW, C. Y.; YANG, C. H. Sporogonic development of the gregarine Ascogregarina taiwanensis (Lien and Levine) (Apicomplexa: Lecudinidae) in its natural host Aedes albopictus (Skuse) (Diptera: Culicidae). Journal of Eukaryotic Microbiology, Cincinnati, v. 44, p. 326-331, 1997.

CHEN, W. J.; YANG, C. H. Developmental synchrony of Ascogregarina taiwanensis (Apicomplexa: Lecudinidae) within Aedes albopictus (Diptera: Culicidae). Journal of Medical Entomology, Lanham, v. 33, p. 212-215, 1996.

CHOUIN-CARNEIRO, T.; VEGA-RUA, A.; VAZEILLE, M.; YEBAKIMA, A.; GIROD, R.; GOINDIN, D.; DUPONTROUZEYROL, M.; LOURENÇO-DE-OLIVEIRA, R.; FAILLOUX, A. B. Differential susceptibilities of Aedes aegypti and Aedes albopictus from the Americas to Zika Virus. PLOS Neglected Tropical Diseases, San Francisco, v. 3, p. e0004543, 2016.

CLOPTON, R. E. Order Eugregarinorida Léger 1900. In: LEE, J. J.; LEEDALE, G. F.; BRADBURY, P. (Ed.). The illustrated guide to the Protozoa. 2 ed. Lawrence: Allen Press, 2000. p. 213-214.

COMISKEY, N.; LOWRIE, R. C.; WESSON, D. M. Role of habitat components on the bionomics of Aedes albopictus (Diptera: Culicidae) from New Orleans. Journal of Medical Entomology, Lanham, v. 36, p. 313-320, 1999.

COPELAND, R. S.; CRAIG, G. B. Interspecific competition, parasitism, and predation affect development of Aedes hendersoni and $A$. triseriatus (Diptera, Culicidae) in artificial treeholes. Annals of the Entomological Society of America, Washington, v. 85, p. 154-163, 1992.

CRAIG, G. B. The diaspora of the Asian tiger mosquito. In: MCKNIGHT, B. N. (Ed.). Biological pollution: the control and impact of invasive exotic species. Indianapolis: Indiana Academic of Science, 1993. p. 101-120.

DELLAPE, M. E.; MARTI, G. A.; TRANCHIDA, M. C.; GARCIA, J. J. First record of Aedes aegypti (L.) (Diptera: Culicidae) infected by the parasite Ascogregarina culicis (Ross) (Apicomplexa: Lecudinidae) in Argentina. Entomología y Vectores, Rio de Janeiro, v. 12, p. 111-115, 2005.

DESPORTES, I. Systematics of terrestrial and freshwater gregarines In: DESPORTES, I.; SCHREVEL, J. (Ed.). Treatise on Zoology - Anatomy, taxonomy, biology, the gregarines. Vol. 2. Leiden: Koninklijke Brill NV, 2013. p. 7-195.

FANTINATTI, E.; DUQUE, J. E.; SILVA, A. M.; NAVARROSILVA, M. A. Abundance and aggregation egg of Aedes aegypti L. and Aedes albopictus (Skuse) (Diptera: Culicidae) in the north and northwest of the State of Paraná, Brazil. Neotropical Entomology, Piracicaba, v. 36, p. 960-965, 2007.

GANAPATI, P. N.; TATE, P. On the gregarine Lankesteria culicis (Ross), 1898, from the mosquito Aedes (Finlaya) geniculatus (Olivier). Parasitology, Cambridge, v. 39, p. 291-294, 1949.

GARCIA, G. A.; SANTOS, L. M.; VILLELA, D. A.; MACIELDE-FREITAS, R. Using Wolbachia releases to estimate Aedes aegypti (Diptera: Culicidae) population size and survival. PLoS One, Cambridge, v. 11, p. e0160196, 2016. 
GARCIA, J. J.; FUKUDA, T.; BECNEL, J. J. Seasonality, prevalence, and pathogenicity of the gregarine Ascogregarina taiwanensis (Apicomplexa: Lecudinidae) is mosquitoes from Florida. Journal of the American Mosquito Control Association, Washington, v. 10, p. 413-418, 1994.

GENTILE, A. G.; FAY, R. W.; MCCRAY, M. The distribution, ethology and control potential of the Lankesteria culicis (Ross) Aedes aegypti complex in southern United States. Mosquito News, Albany, v. 31, p. 12-17, 1971.

GOLSTEIN, P.; KROEMER, G. Cell death by necrosis: towards a molecular definition. Trends in Pharmacological Sciences, London, v. 32, p. 37-43, 2007.

GUBLER, D. J. Dengue, urbanization and globalization: the unholy trinity of the 21 st century. Tropical Medicine and Health, Nagazaki, v. 39, p. 3-11, 2011.

GUENTHER, K. Uber eine gregarine in Ficalbia dofleini Guenther. Zoologischer Anzeiger, Berlin, v. 44, p. 264-267, 1914.

GUZMAN, M. G.; HARRIS, E. Dengue. Lancet, London, v. 385, p. 453-465, 2015.

HAUSMANN, K.; HÜLSMANN, N.; RADEK, R. Protistology. 3 ed. Stuttgart: E. Schweizerbartsche Buchhandlung (Nägele u. Obermiller), 2003. 379 p.

HAYES, G. R.; HAVERFIELD, L. E. Distribution and density of Aedes aegypti (L.) and Lankesteria culicis (Ross) in Louisiana and adjoining areas. Mosquito News, Albany, v. 31, p. 28-32, 1971.

HENRY, J. E. Natural and applied control of insects by protozoa. Annual Review of Entomology, Palo Alto, v. 26, p. 49-73, 1981.

HEUKELBACH, J.; ALENCAR, C. H.; KELVIN, A. A.; DE OLIVEIRA, W. K.; CAVALCANTI, L. P. G. Zika virus outbreak in Brazil. The Journal of Infection in Developing Countries, Viale San Pietro, v. 28, p. 116-120, 2016.

HUANG, C. G.; TSAI, K. H.; WU, W. J.; CHEN, W. J. Intestinal Expression of $\mathrm{H}+\mathrm{V}$-ATPase in the Mosquito Aedes albopictus is tightly associated with gregarine infection. Journal of Eukaryotic Microbiology, Cincinnati, v. 53, p. 127-135, 2006.

JONES, T. F.; CRAIG, A. S.; NASCI, R. S.; PATTERSON, L. E.; ERWIN, P. C.; GERHARDT, R. R.; USSERY, X. T.; SCHAFFNER, W. Newly recognized focus of La Crosse encephalitis in Tennessee. Clinical Infectious Diseases, Oxford, v. 28, p. 93-97, 1999.

KANDUC, D.; MITTELMAN, A.; SERPICO, R.; SINIGAGLIA, E.; SINHA, A. A.; NATALE, C.; SANTACROCE, R.; DI CORCIA, M. G.; LUCCHESE, A.; DINI, L.; PANI, P.; SANTACROCE, S.; SIMONE, S.; BUCCI, R.; FARBER, E. Cell death: apoptosis versus necrosis (review). International Journal of Oncology, London, v. 21, p. 165-170, 2002.

KRAEMER, M. U.; SINKA, M. E.; DUDA, K. A.; MYLNE, A.; SHEARER, F. M.; BRADY, O. J.; MESSINA, J. P.; BARKER, C. M.; MOORE, C. G.; CARVALHO, R. G.; COELHO, G. E.; VAN BORTEL, W.; HENDRICKX, G.; SCHAFFNER, F.; WINT, G. R.; ELYAZAR, I. R.; TENG, H. J.; HAY, S. I. The global compendium of Aedes aegypti and Ae. albopictus occurrence. Nature, London, v. 2, p. $150035,2015$.

KRAMAR, J. Hromadinka Lankesteria culicis Ross, parasitkomara Aedes (Finlaya) Geniculatus Oliv. Vestn. Ceskoslovenske Zool Spolecnosti, Praga, v. 16, p. 43-49, 1952.
LANTOVA, L.; VOLF, P. Mosquito and sand fly gregarines of the genus Ascogregarina and Psychodiella (Apicomplexa: Eugregarinorida, Aseptatorina) - Overview of their taxonomy, life cycle, host specificity and pathogenicity. Infection, Genetics and Evolution, Amsterdam, v. 28, p. 616-627, 2014.

LEANDER, B. S. Marine gregarines: evolutionary prelude to the apicomplexan radiation? Trends in Parasitology, Amsterdam, v. 24, p. 60-67, 2008.

LELES, R. N.; D'ALESSANDRO, W. B.; LUZ C. Effects of Metarhizium anisopliae conidia mixed with soil against the eggs of Aedes aegypti. Parasitology Research, Heidelberg, v. 110, p. 1579-1582, 2012.

LIEN, S.; LEVINE, N. D. Three new species of Ascocystis (Apicomplexa, Lecudinidae) from mosquitoes. Journal of Protozoology, Los Angeles, v. 27, p. 147-151, 1980.

LIMA-CAMARA, T. N. Emerging arboviruses and public health challenges in Brazil. Revista de Saúde Pública, São Paulo, v. 27, p. S0034-89102016000100602, 2016.

LOUNIBOS, L. P.; BARGIELOWSKI, I.; CARRASQUILLA, M. C.; NISHIMURA, N. Coexistence of Aedes aegypti and Aedes albopictus (Diptera: Culicidae) in Peninsular Florida two decades after competitive displacements. Journal of Medical Entomology, Honolulu, v. 53, p. 1385-1390, 2016.

LU, P.; BIAN, G.; PAN, X.; XI, Z. Wolbachia induces densitydependent inhibition to dengue virus in mosquito cells. PLOS Neglected Tropical Diseases, San Francisco, v. 6, p. e1754, 2012.

MARCHOUX, E.; SALIMBENI, A.; SIMOND, P. L. La fievre jaune. Rapport de lamission francaise. Annales de l'Institut Pasteur, Paris, v. 17, p. 665-673, 1903.

MCCRAY, E. M.; FAY, R. W.; SCHOOF, H. F. The bionomics of Lankesteria culicis and Aedes aegypti. Journal of Invertebrate Pathology, Riverside, v. 16, p. 42-53, 1970.

MONTERO, A. Chikungunya fever - A new global threat. Medicina Clínica, Madrid, v. 145, p. 118-123, 2015.

MORALES, M. E.; OCAMPO, C. B.; CADENA, H.; COPELAND, C. S.; TERMINI, M.; WESSON, D. M. Differential identification of Ascogregarina species (Apicomplexa: Lecudinidae) in Aedes aegypti and Aedes albopictus (Diptera: Culicidae) by polymerase chain reaction. Journal of Parasitology, Lawrence, v. 91, p. 13521356, 2005.

MORRISON, D. A. Evolution of the Apicomplexa: where are we now? Trends in Parasitology, Amsterdam, v. 25, p. 375-382, 2009. MOURY, D. T.; SINGH, D. K.; YADAV, P.; GOKHALE, M. D.; BARDE, P. V.; NARAYAN, N. B.; THAKARE, J. P.; MISHRA, A. C.; SHOUCHE, Y. S. Role of gregarine parasite Ascogregarina culicis (Apicomplexa: Lecudinidae) in the maintenance of Chikungunya virus in vector mosquito. Journal of Eukaryotic Microbiology, Cincinnati, v. 50, p. 379-382, 2003.

MUNSTERMANN, L. E.; LEVINE, N. D. Ascogregarina geniculati sp. n. (Protozoa, Apicomplexa) from the mosquito Aedes geniculatus. Journal of Parasitology, Lawrence, v. 69, p. 769-772, 1983.

MUNSTERMANN, L. E.; WESSON, D. M. First record of Ascogregarina taiwanensis (Apicomplexa: Lecudinidae) in north American Aedes albopictus. Journal of the American Mosquito Control Association, Washington, v. 6, p. 235-243, 1990. 
OTTA, D. A.; ROTT, M. B.; CARLESSO, A. M.; SILVA, O. S. Prevalence of Acanthamoeba spp. (Sarcomastigophora: Acanthamoebidae) in wild populations of Aedes aegypti (Diptera: Culicidae). Parasitology Research, Heidelberg, v. 111, p. 20172022, 2012.

PASSOS, R. A.; TADEI, W. P. Parasitism of Ascogregarina taiwanensis and Ascogregarina culicis (Apicomplexa: Lecudinidae) in larvae of Aedes albopictus and Aedes aegypti (Diptera: Culicidae) from Manaus, Amazon region, Brazil. Journal of Invertebrate Pathology, Riverside, v. 97, p. 230-236, 2008.

PILLAI, J. S.; NEILL, H. J. C.; SONE, P. F. Lankesteria culicis a gregarine parasite of Aedes polynesiensis in Western Samoa. Mosquito News, Albany, v. 36, p. 150-154, 1976.

PORTER, C.H.; DEFOLIART, G. R. Gonotrophic age, insemination, and Ascogregarina infection in a southern Wisconsin population of Aedes triseriatus. Journal of the American Mosquito Control Association, Washington, v. 1, p. 238-240, 1985.

PROPHIRO, J. S. Metodos alternativos para o controle fitoquimico e biologico de Aedes spp. Meigen, 1818 (Diptera: Culicidae). Tese (Doutorado em Ciências Biológicas Entomologia) - Universidade Federal do Paraná, Curitiba. 2013.

PROPHIRO, J. S.; NUNES, T.; OLIVEIRA, J. G.; DANDOLINI, G. W.; SILVA, M. A. N.; SILVA, O. S. First registration and molecular characterization of Ascogregarina taiwanensis in Aedes albopictus and Aedes aegypti in Santa Catarina, south Brazil. Revista da Sociedade Brasileira de Medicina Tropical, Uberaba, 2017 (In press).

PROPHIRO, J. S.; SILVA, O. S.; LUNA, J. E. D.; PICCOLI, C. F.; KANIS, L. A.; SILVA, M. A. N. Aedes aegypti and Aedes albopictus (Diptera: Culicidae): coexistence and susceptibility to temephos, in municipalities with occurrence of dengue and differentiated characteristics of urbanization. Revista da Sociedade Brasileira de Medicina Tropical, Uberaba, v. 44, p. 300-305, 2011.

REEVES, W. K. Oviposition by Aedes aegypti (Diptera: Culicidae) in relation to conspecific larvae infected with internal symbiotes. Journal of Vector Ecology, Moscow, v. 29, p. 159-163, 2004.

REEVES, W. K.; MCCULLOUGH, S. D. Laboratory susceptibility of Wyeomyia smithii (Diptera: Culicidae) to Ascogregarina taiwanensis (Apicomplexa: Lecudinidae). Journal of Eukaryotic Microbiology, Cincinnati, v. 49, p. 391-392, 2002.

REINERT, J. F. New classification for the composite genus Aedes (Diptera: Culicidae: Aedini), elevation of subgenus Ochlerotatus to generic rank, reclassification of the other subgenera, and notes on certain subgenera and species. Journal of the American Mosquito Control Association, Washington, v. 16, p. 175-188, 2000.

REYES-VILLANUEVA, F.; BECNEL, J. J.; BUTLER, J. F. Morphological traits for distinguishing extracellular gamonts of Ascogregarina culicis and Ascogregarina taiwanensis in Aedes aegypti and Aedes albopictus. Journal of Invertebrate Pathology, Riverside, v. 77, p. 227-229, 2001.

REYES-VILLANUEVA, F.; BECNEL, J. J.; BUTLER, J. F. Susceptibility of Aedes aegypti and Aedes albopictus larvae to Ascogregarina culicis and Ascogregarina taiwanensis (Apicomplexa: Lecudinidae) from Florida. Journal of Invertebrate Pathology, Riverside, v. 84, p. 47-53, 2003.

REYES-VILLANUEVA， F.; GARZA-HERNANDEZ， J. A.; GARCIA-MUNGUIA, A. M.; HOWARD, A. F.; ORTEGA-
MORALES, A. I.; ADELEKE, M. A.; RODRIGUEZ-PEREZ, M. A. Aedes albopictus in northeast Mexico: An update on adult distribution and first report of parasitism by Ascogregarina taiwanensis. Journal of Vector Borne Diseases, New Delhi, v. 50, p. 202-205, 2013.

ROSS, R. Report on preliminary investigation into malaria in Sigur Ghat, Ootacamund. Transactions of the South Indian Branch of the British Medical Association, London, v. 8, p. 143-152, 1898.

ROYCHOUDHURY, S.; ISAWA, H.; HOSHINO, K.; SASAKI, T.; SAITO, N.; SAWABE, K.; KOBAYASHI, M. Comparison of the morphology of oocysts and the phylogenetic analysis of four Ascogregarina species (Eugregarinidae: Lecudinidae) as inferred from small subunit ribosomal DNA sequences. Parasitology International, Amsterdam, v. 56, p. 113-118, 2007a.

ROYCHOUDHURY, S.; ISAWA, H.; HOSHINO, K.; SASAKI, T.; SAITO, N.; SAWABE, K.; KOBAYASHI, M. The new species of Ascogregarina from Ochlerotatus japonicus japonicas. Medical Entomology and Zoology, Tokyo, v. 58, p. A06, 2007 b.

ROYCHOUDHURY, S.; KOBAYASHI, M. New findings on the developmental process of Ascogregarina taiwanensis and Ascogregarina culicis in Aedes albopictus and Aedes aegypti. Journal of the American Mosquito Control Association, Washington, v. 22, p. 29-36, 2006.

SALOKHE, S. G.; DESHPANDE, S. G.; MUKHERJEE, S. N. Evaluation of the insect growth regulator Lufenuron (Match $\left.{ }^{\circledR}\right)$ for control of Aedes aegypti by simulated field trials. Parasitology Research, Heidelberg, v. 111, p. 1325-1329, 2012.

SÁNCHEZ-TRINIDAD, A.; ORDOÑEZ-SÁNCHEZ, F.; VALDES-PEREZGASGA, M. T.; SÁNCHEZ-RAMOS, F. J.; ZAVORTINK, T. J.; CORTÉS-GUZMÁN, A. J.; ORTEGAMORALES, A. I. Geographical distribution of the Aedes triseriatus Group (Diptera: Culicidae) in Mexico. Journal of Vector Ecology, Moscow, v. 39, p. 134-137, 2014.

SANDERS, R. D.; POINAR, G. O. Fine structure and life cycle of Lankesteria clarki sp. n. (Sporozoa: Eugregarinida) parasitic in the mosquito Aedes sierrensis (Ludlow). Journal of Protozoology, Los Angeles, v. 20, p. 594-602, 1973.

SILVA, O. S.; PRADO, G. R.; DA SILVA, J. L.; SILVA, C. E.; DA COSTA, M.; HEERMANN, R. Oral toxicity of Photorhabdus luminescens and Xenorhabdus nematophila (Enterobacteriaceae) against Aedes aegypti (Diptera: Culicidae). Parasitology Research, Heidelberg, v. 112, p. 2891-2896, 2013.

SMITH, L. B.; KASAI, S.; SCOTT, J. G. Pyrethroid resistance in Aedes aegypti and Aedes albopictus: Important mosquito vectors of human diseases. Pesticide Biochemistry and Physiology, Amherst, v. 133, p. 1-12, 2016.

SPENCER, J. P.; OLSON, J. K. Evaluation of the combined effects of methoprene and the protozoan parasite Ascogregarina culicis (Eugregarinida, Diplocystidae), on Aedes mosquitoes. Mosquito News, Albany, v. 42, p. 384-390, 1982.

STAPLES, J. E.; FISCHER, M. Chikungunya virus in the Americas - What a vector borne pathogen can do. The New England Journal of Medicine, Boston, v. 371, p. 887-889, 2014.

STAPP, R. R.; GASTEN, J. Field studies on Lankesteria culicis and Aedes aegypti in Florida. Mosquito News, Albany, v. 31, p. 18-22, 1971. 
SULAIMAN, I. Infectivity and pathogenicity of Ascogregarina culicis (Eugregarinida: Lecudinidae) to Aedes aegypti (Diptera: culicidae). Journal of Medical Entomology, Lanham, v. 29, p. $1-4,1992$.

TROUT FRYXELL, R. T.; FREYMAN, K.; ULLOA, A.; HENDRICKS, B.; PAULSEN, D.; ODOI, A.; MONCAYO, A. Cemeteries are effective sites for monitoring la crosse virus ( $\mathrm{LACV}$ ) and these environments may play a role in LACv infection. PloS One, Cambridge, v. 10, n. 4, e0122895, 2015.

TSENG, M. Ascogregarine parasites as possible biocontrol agents of mosquitoes. Journal of the American Mosquito Control Association, Washington, v. 23, p. 30-34, 2007.

VAN RHEIN, S. L.; FLANARY, B. E.; JULIANO, S. A. Effects of habitat type and drying on Ascogregarina barretti (Eugregarinida: Lecudinidae) infection in Aedes triseritatus (Diptera: Culicidae). Journal of Medical Entomology, Lanham, v. 37, p. 950-956, 2000.

VAVRA, J. Lankesteria barretti n. sp. (Eugregarinida, Diplocystidae), a parasite of the mosquito Aedes triseriatus (Say) and a review of the genus Lankesteria Mingazzini. Journal of Protozoology, Los Angeles, v. 16, p. 546-570, 1969.

VEZZANI, D.; WISNIVESKY, C. Prevalence and seasonality of Ascogregarina culicis (Apicomplexa: Lecudinidae) in natural populations of Aedes aegypti (Diptera: Culicidae) from temperate Argentina. Journal of Invertebrate Pathology, Riverside, v. 91,p. 183-187, 2006.

VIEIRA, C. J.; SILVA, D. J.; BARRETO, E. S.; SIQUEIRA, C. E.; COLOMBO, T. E.; OZANIC, K.; SCHMIDT, D. J.; DRUMOND, B. P.; MONDINI, A.; NOGUEIRA, M. L.; BRONZONI, R. V. Detection of Mayaro virus infections during a dengue outbreak in Mato Grosso, Brazil. Acta Tropica, Amsterdam, v. 147, p. 12-16, 2015.

VIVIER, E.; DESPORTES, I. Phylum Apicomplexa. In: MARGULIS, L.; CORLISS, J. O.; MELKONIAN, M.; CHAPMAN, D. J. (Ed.). The hand book of Protoctista. Boston: Jones and Bartlett, 1990. p. 1-21.
VOTÝPKA, J.; LANTOVA, L.; GHOSH, K.; BRAIG, H.; VOLF, P. Molecular characterization of gregarines from sand flies (Diptera: Psychodidae) and description of Psychodiella ng (Apicomplexa: Gregarinida). Journal of Eukaryotic Microbiology, Cincinnati, v. 56, p. 583-588, 2009.

WALKER, E. D.; POIRIER, S. J.; VELDMAN, W. T. Effects of Ascogregarina barretti (Eugregarinida: Lecudinidae) infection on emergence success, development time, and size of Aedes triseriatus (Diptera: Culicidae) in microcosms and tires. Journal of Medical Entomology, Lanham, v. 24, p. 303-309, 1987.

WALSH, R. D.; OLSON, J. K. Observations on the susceptibility of certain mosquito species to infection by Lankesteria culicis (Ross). Mosquito News, Albany, v. 36, p. 536-545, 1976.

WEAVER, S. C.; FORRESTER, N. L. Chikungunya: Evolutionary history and recent epidemic spread. Antiviral Research, Leuven, v. 120 , p. 32-33, 2015.

WENYON, C. M. Oriental sore in Bagdad, together with observations on a gregarine in Stegomyia fasciata, the haemogregarine of dogs and the flagellates of house flies. Parasitology, Cambridge, v. 4, p. 273-344, 1911.

WESTBY, K. M.; FRITZEN, C.; PAULSEN, D.; POINDEXTER, S.; MONCAYO, A. C. La Crosse Encephalitis Virus Infection in field-collected Aedes albopictus, Aedes japonicus, and Aedes triseriatus in Tennessee. Journal of the American Mosquito Control Association, Washington, v. 31, p. 233-241, 2015.

WETZEL, D. M.; HÅKANSSON, S.; HU, K.; ROOS, D.; SIBLEY, L. D. Actin filament polymerization regulates gliding motility by apicomplexan parasites. Molecular Biology of the Cell, Bethesda, v. 14, p. 396-406, 2003.

YEH, M. L.; CHEN, C. S.; LIU, K. C. Experimental infection of mosquitoes with two Ascogregarina species (Eugregarinida: Lecudinidae). Bulletin of Tung Hai University, Taichung City, v. 35, p. 87-106, 1994. 